\title{
Regulatory Prospects of Clinical Trials with Stem Cells in the United Arab Emirates
}

\author{
Yandy Marx Castillo-Aleman, MD* (D), Yendry Ventura-Carmenate, MD (iD, Rene Antonio \\ Rivero-Jimenez, Ph.D (D) and Antonio Alfonso Bencomo-Hernandez, Ph.D
}

Abu Dhabi Stem Cells Center (ADSCC), UAE

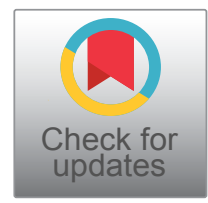

*Corresponding author: Dr. Yandy Marx Castillo Aleman, MD, Clinical Immunology Specialist, Department of Immunology, Abu Dhabi Stem Cells Center (ADSCC), United Arab Emirates, Tel: (+971) 2665-5155, ext. 104; (+971)-50144-5761

\begin{abstract}
Health research and clinical trials are driving the development of valuable medical knowledge. Many types of clinical research have been conducted in the United Arab Emirates (UAE) by governmental and private health providers in recent years, and a growing number of publications and UAE-based clinical trials have been registered worldwide. However, there are wide differences between the Emirates regarding the policies governing emerging stem cell therapies. This article aims to discuss the regulatory framework for conducting clinical trials involving stem cell therapies in the UAE. UAE-based clinical trials with stem cells were searched in international registries and national databases. Two health authorities are leading regulatory affairs on stem cells and regenerative medicine: The Department of Health - Abu Dhabi and Dubai Health Authority, while the public databases revealed 7 studies that investigated stem cells in the UAE. We recommend increasing the inter-organizational relationships between health authorities and regulated parties.
\end{abstract}

\section{Keywords}

Clinical trial, Policy, Health planning, National health programs, Health care reform

\section{Introduction}

Clinical research has played a significant role in maintaining human health driving medical knowledge generation and development. In the United Arab Emirates (UAE), the government, several hospitals, universities, and governmental and private healthcare providers have recently been taking invaluable measures to maintain the clinical research culture as a public health priority. In this regard, an increasing number of publications and clinical trials have been reported in the UAE.

Innovative therapies with biological products such as stem cells have been introduced, making it is necessary to review the current state of the UAE's regulatory framework. The research on stem cells and regenerative medicine is growing at an exceptional rate. Still, the safety and effectiveness of applying stem cell therapies have been focused on insufficient evidence in some instances worldwide. Nevertheless, it is suggested that they are groundbreaking therapies for different conditions. Several cell therapies have been established as promising strategies in treating various diseases, and some have obtained marketing authorization from regulatory agencies.

"Biological products" have been defined and regulated by the United States (US) Food and Drug Administration (FDA) [1], and more recently, a final rule has amended the definition by making technical revisions and conforming to the statutory definition [2].

As biological products, stem cells possess both selfrenewal and multipotency capacities to differentiate into various cell types, which have potential therapeutic significance. Thus, a considerable amount of basic, preclinical, and clinical studies have examined them. However, unproven stem cell therapies can be inefficacious, inefficient, or unsafe. In this regard, health authorities have issued several statements against using unproven cell-based therapies [3,4]. 
Consequently, the most accepted pathway to demonstrate their safety and effectiveness in clinical settings is through clinical trials that follow the Good Clinical Practices (GCP) guidelines. The aim of this article is to address the UAE's regulatory prospects regarding clinical trials with stem cells. The current status is analyzed, and recommendations are provided.

\section{Regulatory Prospects}

Health regulation is essential for translating innovative products from research and development activities to clinical settings while ensuring compliance with highquality requirements. The classification of stem cells as biological products would lead to a more comprehensive regulatory structure that specifies production criteria and marketing authorization applications.

\section{UAE healthcare system and regulatory framework}

The Ministry of Health and Prevention (MOHAP) is the UAE's federal health authority and provides comprehensive healthcare services. Since the establishment of individual emirate-based healthcare authorities by the Abu Dhabi Department of Health (DOH) and the Dubai Health Authority (DHA), the focus of MOHAP has shifted to the five Northern Emirates [5].

In the Dubai healthcare free zone, the Dubai Healthcare City Authority - Regulatory (DHCR) acts as an independent regulatory arm. Accordingly, the MOHAP, $\mathrm{DOH}, \mathrm{DHA}$, and DHCR are considered the principal authorities regulating health research and clinical trial authorizations.

Each of these regulatory bodies follows different policies and procedures concerning clinical research, adhering to GCP guidelines and maintaining research ethics in their jurisdictions [6]. The most relevant standards can be summarized as follows: "Guidance for conducting clinical trials based on drugs/medical products and good clinical practice" (MOHAP, 2006), "DOH guidelines for conducting clinical trials with investigational products and medical devices" (2020), "DOH standard on human subject research" (2020), "Code of conduct for healthcare professionals" (DHA, 2014), and "Conducting research in Dubai Healthcare City" (DHCR, 2019).

Nevertheless, only two Emirates lead regulation of the stem cells and cell products, which have established public guidelines for the regulated sector. These current standards are applied to the Dubai healthcare sector: "Platelet Rich Plasma Guidelines" (DHA, 2014) and "Standards for autologous adipose-tissue derived stem cells/stromal vascular fraction cells therapy" (DHA, 2020). For Abu Dhabi healthcare stakeholders, the following have been issued: "DOH standard on stem cell therapies, products and regenerative medicine" (2019) and the "DOH standard for centers of excellence in hematopoietic stem cell transplantation services for adults and pediatrics" (2019). These regulatory frameworks have represented a milestone regarding the research and preclinical or clinical applications of stem cell-based therapies and cell-derived products in both Dubai and Abu Dhabi in recent years. In addition, these standards have adopted international scientific evidence and good practices to enhance the highquality services related to the collection, processing, and administration requirements.

It is also necessary to mention the significant role of the different institutional review boards (IRBs) and research ethics committees (RECs) in regulating medical research and clinical trials. Several committees ensure compliance with ethical standards, the protection of subjects' rights, and scientific research principles, including the design, analysis, and methodology used in research in the UAE. Some of the IRBs or RECS are entirely associated with universities, healthcare facilities, or government/health authorities [e.g., Dubai Scientific Research Ethics Committee (DSREC) and the Abu Dhabi Health Research and Technology Committee (ADHRTC)]. Controversially, as there are no national standards to follow, the framework needs to be updated to harmonize the relevant policies, regulations, and ethics for human research in the UAE.

\section{International clinical studies registries}

An increasing number of medical research studies reported by the UAE (Figure 1A). Some of such studies have been registered to investigate biological-based therapies in international clinical trials registries. The registration in a public registry is a requirement of the International Committee of Medical Journal Editors (ICMJE) [7], which accepts registration at ClinicalTrials. gov [8], one of the most recognized Data Providers of the WHO International Clinical Trials Registry Platform (ICTRP), or in any primary register of the WHO ICTRP [9], as follow:

- Australian New Zealand Clinical Trials Registry (ANZCTR)

- Brazilian Clinical Trials Registry (ReBec)

- Chinese Clinical Trial Registry (ChiCTR)

- Clinical Research Information Service (CRiS) Republic of Korea

- Clinical Trials Registry - India (CTRI)

- Cuban Public Registry of Clinical Trials (RPCEC)

- EU Clinical Trials Register (EU-CTR)

- German Clinical Trials Register (DRKS)

- Iranian Registry of Clinical Trials (IRCT)

- International Standard Randomized Controlled Trial Number (ISRCTN)

- Japan Primary Registries Network (JPRN) 
A)

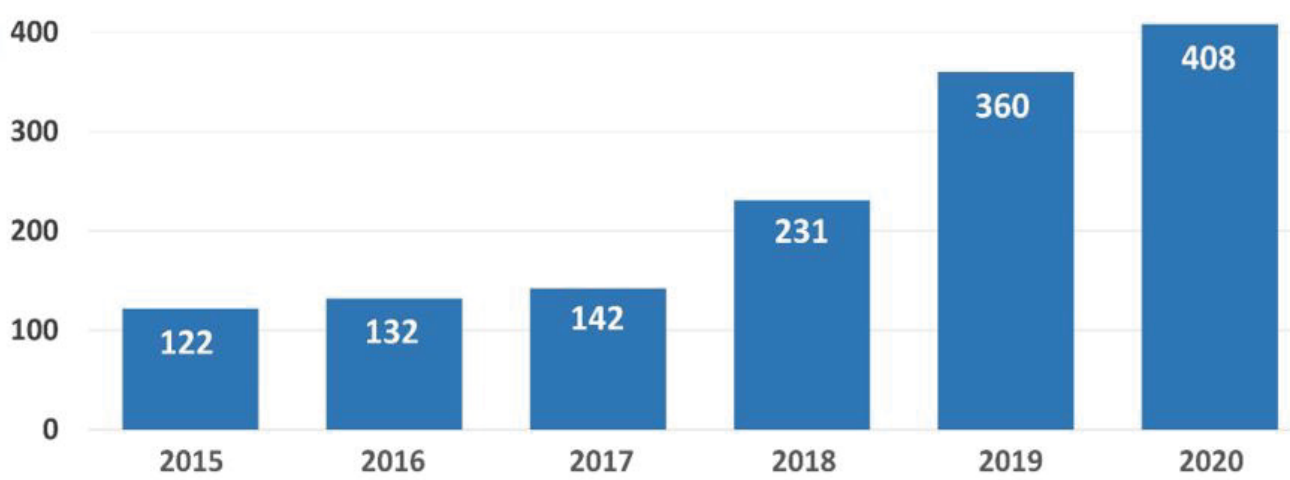

B)

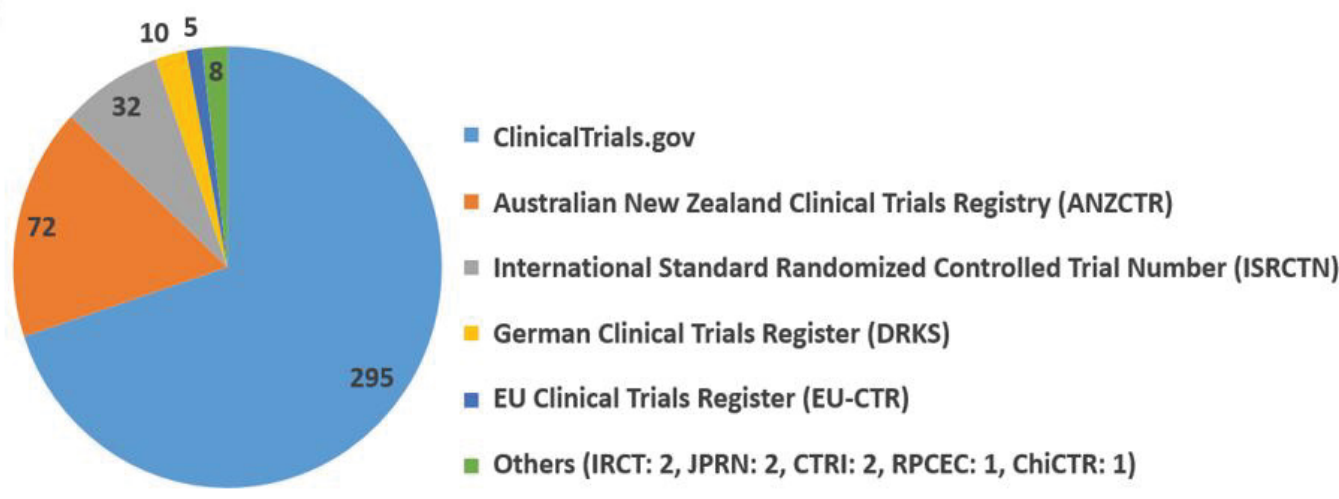

Figure 1: Registration of UAE-based clinical studies in public registries.

(A) Health research studies registered by the UAE MOHAP

Source: UAE Research Bank [10] (As of September 23 ${ }^{\text {rd }}$, 2021, 227 studies have been recorded in this database for 2021, not shown in Figure).

(B) UAE-based clinical studies in WHO network registries.

Source: ClinicalTrials.gov [8] and primary registries in the WHO ICTRP [9] (As of September 23 ${ }^{\text {rd }}$, 2021).

For location search purposes in these platforms, the terms "United Arab Emirates" and "UAE" were included (Figure 1B). Most of the studies found were registered at ClinicalTrials.gov (295 studies), followed by ANZCTR and ISRCTN databases ( 72 and 32 studies, respectively).

There are different ongoing clinical trials with biological products in the UAE. For example, there are registered various studies regarding the assessment of vaccines, such as "A Study to Evaluate the Efficacy, Safety and Immunogenicity of Inactivated SARS-COV-2 Vaccines (Vero Cell) in Healthy Population Aged 18-Years-Old and Above (COVID-19): NCT04510207." Additional trials with other biological products have been done according to the ClinicalTrials.gov database, such as "Phase IV-Cervical Dystonia (INTEREST_INCD2): NCT01753349." One UAEbased clinical trial investigated platelet-rich plasma ("Will Autologous Platelet Rich Plasma Able to Restore Ovarian Function? NCT04381299"). Another study, "Management of Tear Trough Deformity: NCT04538716" investigated the application of stromal vascular fraction gel (SVF-gel) [8]. Other terms were included to refine the general overview, such as "biological," "vaccine," "platelet rich plasma," and "stromal vascular fraction."
However, out of 295 clinical studies, only 6 clinical trials that investigated stem cells were found in the ClinicalTrials.gov databases: Two are declared as completed, and four other trials are currently conducting recruitment (Table 1). For searches including the products investigated, the following terms were applied: "stem cell(s)," "hematopoietic," and "progenitor cell(s)."

Both completed studies examined autologous non-hematopoietic peripheral blood stem cells and were sponsored by the "Abu Dhabi Stem Cells Center (ADSCC)," an Abu Dhabi-based medical center. The four ongoing studies were funded by "MD Stem Cells," a US-based company, to be conducted in Dubai. Interestingly, these six studies have been sponsored by two companies, and they were based in Emirates with established frameworks for the regulation of stem cell products: Abu Dhabi and Dubai.

\section{National clinical trials registries}

The UAE MOHAP has posted the Health Research Bank, but not all of its studies are clinical trials; it includes descriptive, correlational, and quasi-experimental studies. During the current coronavirus pandemic, 
Table 1: Registration of UAE-based clinical trials with stem cells in ClinicalTrials.gov Registry, 2021.

\begin{tabular}{|c|c|c|c|c|c|}
\hline NCT No. & Title & Status & Sponsor & $\begin{array}{l}\text { Administration } \\
\text { route* / Product }\end{array}$ & $\begin{array}{l}\text { Diseases / } \\
\text { Conditions }\end{array}$ \\
\hline NCT04473170 & $\begin{array}{l}\text { Study Evaluating the Safety } \\
\text { and Efficacy of Autologous } \\
\text { Non-Hematopoietic Peripheral } \\
\text { Blood Stem Cells in COVID-19 } \\
\text { (SENTAD-COVID) }\end{array}$ & Completed & $\begin{array}{l}\text { Abu Dhabi } \\
\text { Stem Cells } \\
\text { Center, UAE }\end{array}$ & $\begin{array}{l}\text { NB / Autologous } \\
\text { Non-Hematopoietic } \\
\text { Peripheral Blood } \\
\text { Stem Cells }\end{array}$ & $\begin{array}{l}\text { COVID-19 } \\
\text { pneumonia/ } \\
\text { Acute respiratory } \\
\text { distress syndrome } \\
\text { (ARDS) }\end{array}$ \\
\hline NCT04645485 & $\begin{array}{l}\text { Safety and Tolerability of } \\
\text { Autologous Non-Hematopoietic } \\
\text { Peripheral Blood Stem Cells } \\
\text { Therapy in Healthy Adult } \\
\text { Volunteers (SANTANA) }\end{array}$ & Completed & $\begin{array}{l}\text { Abu Dhabi } \\
\text { Stem Cells } \\
\text { Center, UAE }\end{array}$ & $\begin{array}{l}\text { NB / Autologous } \\
\text { Non-Hematopoietic } \\
\text { Peripheral Blood } \\
\text { Stem Cells }\end{array}$ & $\begin{array}{l}\text { Healthy Adult } \\
\text { Volunteers }\end{array}$ \\
\hline NCT02795052 & $\begin{array}{l}\text { Neurologic Stem Cell Treatment } \\
\text { Study (NEST) }\end{array}$ & Recruiting & $\begin{array}{l}\text { MD Stem } \\
\text { Cells, US }\end{array}$ & $\begin{array}{l}\text { IV / Autologous Bone } \\
\text { Marrow Derived } \\
\text { Stem Cells }\end{array}$ & $\begin{array}{l}\text { Different } \\
\text { neurologic } \\
\text { disorders }\end{array}$ \\
\hline NCT03011541 & $\begin{array}{l}\text { Stem Cell Ophthalmology } \\
\text { Treatment Study II (SCOTS2) }\end{array}$ & Recruiting & $\begin{array}{l}\text { MD Stem } \\
\text { Cells, US }\end{array}$ & $\begin{array}{l}\text { RB, ST, IV / } \\
\text { Autologous Bone } \\
\text { Marrow Derived } \\
\text { Stem Cells }\end{array}$ & $\begin{array}{l}\text { Different retinal } \\
\text { and optic nerve } \\
\text { diseases }\end{array}$ \\
\hline NCT03724136 & $\begin{array}{l}\text { Alzheimer's Autism and } \\
\text { Cognitive Impairment Stem Cell } \\
\text { Treatment Study (ACIST) }\end{array}$ & Recruiting & $\begin{array}{l}\text { MD Stem } \\
\text { Cells, US }\end{array}$ & $\begin{array}{l}\text { RB, ST, IV / } \\
\text { Autologous Bone } \\
\text { Marrow Derived } \\
\text { Stem Cells }\end{array}$ & $\begin{array}{l}\text { Alzheimer's } \\
\text { disease, other } \\
\text { dementias, and } \\
\text { autism spectrum } \\
\text { disorders }\end{array}$ \\
\hline NCT03225625 & $\begin{array}{l}\text { Stem Cell Spinal Cord Injury } \\
\text { Exoskeleton and Virtual Reality } \\
\text { Treatment Study (SciExVR) }\end{array}$ & Recruiting & $\begin{array}{l}\text { MD Stem } \\
\text { Cells, US }\end{array}$ & $\begin{array}{l}\text { PA, IV, IN / } \\
\text { Autologous Bone } \\
\text { Marrow Derived } \\
\text { Stem Cells }\end{array}$ & $\begin{array}{l}\text { Spinal Cord } \\
\text { Injuries }\end{array}$ \\
\hline
\end{tabular}

Source: ClinicalTrials.gov [8].

*NB: Nebulization; IV: Intravenous; RB: Retrobulbar; ST: Subtenon; PA: Paraspinal; IN: Intranasal.

Table 2: Registration of clinical trials with stem cells in the UAE COVID-19 National Research Registry, 2021.

\begin{tabular}{|c|c|c|c|c|c|}
\hline $\begin{array}{l}\text { Ref. } \\
\text { No. }\end{array}$ & Title & Status & Sponsor & $\begin{array}{l}\text { Administration } \\
\text { route }^{*} \text { / Product }\end{array}$ & $\begin{array}{l}\text { Diseases / } \\
\text { Conditions }\end{array}$ \\
\hline 27 & $\begin{array}{l}\text { Intra-Vein Injection of allogeneic } \\
\text { mesenchymal stem cells for support } \\
\text { of COVID-19 patients }\end{array}$ & Pending & $\begin{array}{l}\text { King's College } \\
\text { Hospital London, } \\
\text { UAE }\end{array}$ & $\begin{array}{l}\text { IV / Mesenchymal } \\
\text { Stem Cells }\end{array}$ & $\begin{array}{l}\text { COVID-19 } \\
\text { patients }\end{array}$ \\
\hline 52 & $\begin{array}{l}\text { Phase } 3 \text { Clinical Trial for the usage } \\
\text { of mesenchymal stem cells (MSC) } \\
\text { and high doses of vitamin C to treat } \\
\text { COVID } 19 \text { patients at Dubai Health } \\
\text { Authority }\end{array}$ & Completed & $\begin{array}{l}\text { Dubai Cord Blood } \\
\text { \& Research Center, } \\
\text { UAE }\end{array}$ & $\begin{array}{l}\text { IV / Mesenchymal } \\
\text { Stem Cells }\end{array}$ & $\begin{array}{l}\text { Severe } \\
\text { COVID-19 } \\
\text { patients }\end{array}$ \\
\hline 7 & $\begin{array}{l}\text { Usage of stem cells to treat } \\
\text { coronavirus disease } 2019 \\
\text { (COVID-19) patients }\end{array}$ & Not-approved & $\begin{array}{l}\text { Dubai Cord Blood } \\
\text { \& Research Center, } \\
\text { UAE }\end{array}$ & Not specified & $\begin{array}{l}\text { COVID-19 } \\
\text { patients }\end{array}$ \\
\hline 1 & $\begin{array}{l}\text { Clinical Efficacy of Autologous } \\
\text { Stromal Vascular Fraction (SVF) for } \\
\text { Acute COVID-19 Infection }\end{array}$ & Not-approved & $\begin{array}{l}\text { Cell Surgical } \\
\text { Network, US }\end{array}$ & $\begin{array}{l}\text { Not specified / } \\
\text { Stromal Vascular } \\
\text { Fraction (SVF) }\end{array}$ & $\begin{array}{l}\text { COVID-19 } \\
\text { patients }\end{array}$ \\
\hline
\end{tabular}

Source: UAE COVID-19 Research Registry platform [11].

*IV: Intravenous.

the Abu Dhabi DOH has introduced an open national research registry platform to gather all research activities related to COVID-19 [11]. There are two approved and unapproved clinical trials that used stem cells in the COVID-19 research registry platform, and the leading Emirates are Dubai [Ref.7,27,52] and Abu Dhabi [Ref.1], as shown in Table 2.

\section{UAE regulatory strategies}

The aim of physicians and researchers is for biological-based therapies to be successfully applied in treating many diseases and conditions. However, published evidence has mainly been derived from small, uncontrolled trials plus a few controlled, randomized trials, which have not consistently demonstrated the 
safety and efficacy of stem cell therapies in various study conditions [4]. For many healthcare providers, it is difficult to conduct well-designed and high-quality clinical trials and to comply with regulatory guidelines for such promising treatments. Nevertheless, these efforts should be mandatory in our opinion.

The UAE regulatory framework is changing in research settings by implementing innovative strategies. Recent resolutions and ministerial decisions of the UAE Cabinet (Council of Ministers) include the Central Database for Researchers and Research and the establishment of the National Center for Health Research. This database will be a centralized, comprehensive, and searchable online database, while the research center will provide a framework for harmonizing policies, procedures, and ethics for human research in the UAE. This center shall unify and standardize the regulations for granting approvals for research studies and clinical trials in the UAE, identifying priorities, and coordinating national flagship projects [12].

The healthcare environment is one of the most dynamic business fields in the UAE. Thus, it is recommended that the inter-organizational relationships between the regulatory authorities and the regulated sector be strengthened, particularly with the biotechnology industry associated with stem cell research and stakeholders in clinical trials. Promoting strategies like the standard draft reviews, interactions during workshops, seminars, training courses, conferences, and utilizing eLearning tools, among others, could enhance the development of regulations and improve compliance by the regulated parties.

\section{Conclusions}

Policies governing the regulation of stem cells and overall biological products vary widely in the UAE, and there are prominent leaders in the Abu Dhabi and Dubai health authorities. An increase in medical research on cell therapies requires strengthening the regulatory framework on health research and clinical trials. In this regard, the UAE Cabinet has recently approved a set of legislation to support the healthcare sector, such as establishing the Central Database for Researchers and Research and the National Center for Health Research. Thus, it is recommended that the inter-organizational relationships between the regulatory authorities and the regulated sector be strengthened. These strategies are meant guarantee to harmonize standards and policies for clinical research, identifying priorities, and coordinating the most relevant national projects, including stem cells research.

\section{Funding Sources}

None of the authors have obtained external funding anywhere. Therefore, this manuscript was funded by the authors themselves.

\section{Authors' Contributions}

YMCA: Conception and design, acquisition of data, analysis and interpretation of data, drafting of the manuscript, and critical revision of the manuscript before submitting for publication; YVC, RARJ, AABH: Drafting the manuscript, and critical revision of the manuscript before submitting for publication.

All authors are responsible for the final approval of the version to be published. Authors agree to be accountable for all aspects of the work in ensuring that questions related to the accuracy or integrity of any part of the work are appropriately investigated and resolved.

\section{Conflict of Interest}

The authors are Abu Dhabi Stem Cells Center (ADSCC) employees, a sponsor facility of two clinical trials cited in Table 1 (Ref. NCT04473170 and NCT04645485).

The authors own three copyrighted Works of Science (related to these trials) issued by the INTEROCO Copyright Office (Dubai, UAE) with Ref. EC-01-002809, EC-01-002810, and EC-01-002811.

\section{References}

1. Biological product (2011) United States Code, U.S.C. Title 42. The public health and welfare 2011: 373.

2. US Federal Register (2020) Rules and Regulations 85: 10057.

3. EMA Committee for Advanced Therapies (2020) European Medicines Agency warns against using unproven cellbased therapies.

4. Marks PW, Witten CM, Califf RM (2017) Clarifying StemCell Therapy's Benefits and Risks. N Engl J Med 376: 1007-1009.

5. United Arab Emirates' Government portal. Health regulatory authorities.

6. Kumar AS (2015) Clinical research in the United Arab Emirates. Journal for Clinical Studies 6: 30-31.

7. (2018) WHO International Standards for Clinical Trial Registries.

8. http://www.clinicaltrials.gov

9. $\mathrm{WHO}$ (2021) Primary registries in the WHO registry network.

10. UAE Research Bank.

11. Abu Dhabi Department of Health. COVID-19 Research Registry platform.

12. (2020) National Center for Health Research. Ministry of Health and Prevention (MOHAP). 